\title{
The Oripää granite revisited: Elemental geochemistry, Nd isotopes, and implication to terrane boundary
}

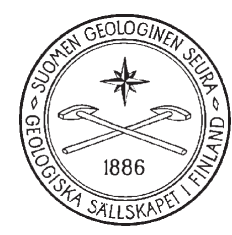

\author{
MikKo NiRONEN ${ }^{1) *}$ AND O. TAPANI RÄMÖ ${ }^{2)}$ \\ 1) Geological Survey of Finland, P.O. Box 96, FI-02151 Espoo, Finland \\ 2) Department of Geosciences and Geography, Division of Geology, \\ P.O. Box 64, FI-00014 University of Helsinki, Finland
}

Key words: granites, tonalite, quartz diorites, amphibolites, geochemistry, isotopes, $\mathrm{Sm} / \mathrm{Nd}$, Paleoproterozoic, Oripää, Finland

* Corresponding author e-mail: mikko.nironen@gtk.fi

Editorial handling: Joonas Virtasalo

\section{Introduction}

The Paleoproterozoic Oripää granite in the Loimaa area in southwestern Finland (Fig. 1a; Nironen, 1999) is a small, heterogeneous leucogranite pluton that was emplaced within the synorogenic $(1.89-1.87 \mathrm{Ga})$ plutonic and supracrustal rocks of the Arc complex of southern Finland at $-1.85 \mathrm{Ga}$ (Kurhila et al., 2005, 2011). The Oripää granite has been considered to belong to the "microcline granites" (leucogranites) of the Late Svecofennian granite-migmatite zone (LSGM zone; Ehlers et al., 1993). In terms of its relatively radiogenic $\mathrm{Nd}$ isotope character (positive initial $\varepsilon_{\mathrm{Nd}}$ value) and relatively old age (Rämö \& Nironen, 2001; Kurhila et al., 2005) it is, however, rather different from the main leucogranite bodies of the LSGM farther south. We have analyzed new samples from the Oripää granite and its country rocks (tonalite, quartz diorite, amphibolite) for $\mathrm{Nd}$ isotopes and elemental geochemistry in order to further characterize the Oripää granite and the bedrock around it. Our results show that the Oripää granite is consanguineous with its immediate country rocks and that the terrane boundary marking transition from the Arc complex of western Finland to the Arc complex of southern Finland is located just north of the Oripää granite at this longitude.

\section{Geologic setting}

The area denoted as Oripää granite (Fig. 1) is heterogeneous, consisting of supracrustal rocks and synorogenic plutonic rocks injected and migmatized by pink, generally coarse-grained leucogranite. The main target of our study is a rock quarry at the northern margin of the Oripää granite. The main rock type at the Oripää quarry is a synorogenic plu- 


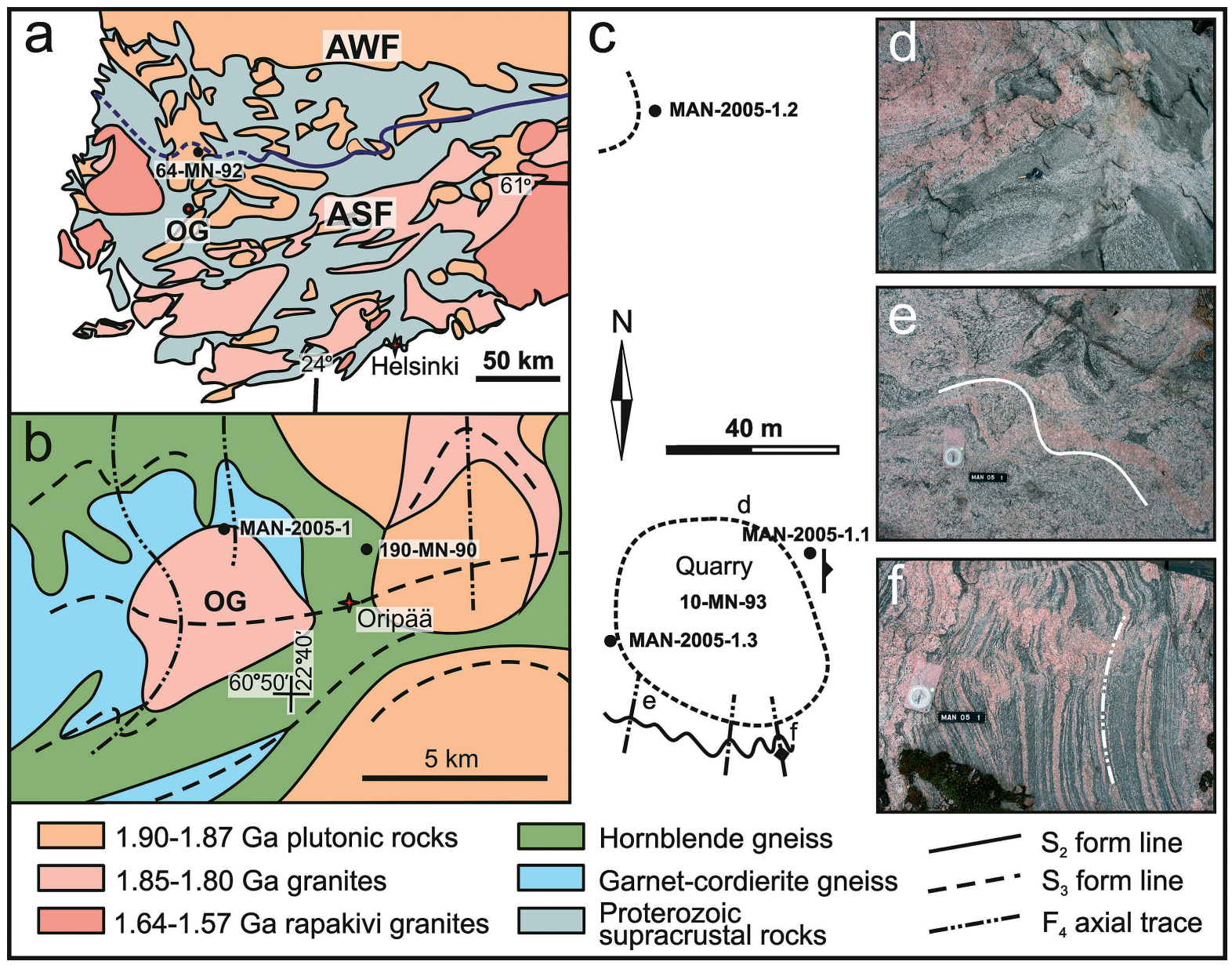

Fig. 1. Geological features of the Oripää granite. a) Location of the Oripää granite (OG) in southern Finland; location of sample 64-MN-92 is also shown. ASF = Arc complex of southern Finland, AWF = Arc complex of western Finland. b) Lithology and structures around the Oripää granite. c) Sketch of the Oripää quarry (sample site MAN-2005-1 in Fig. 1b). Structures as well as sample and photo sites are shown. d) Synorogenic, foliated tonalitic - quartz dioritic rock with amphibolitic inclusions, crosscut by coarse leucogranite (Oripää granite). Length of key $7 \mathrm{~cm}$. e) Synorogenic, foliated and openly folded (F4) granodioritic - tonalitic rock crosscut by leucogranite veins subparallel to foliation. Length of code bar $12 \mathrm{~cm}$. f) Synorogenic, foliated tonalitic - quartz dioritic rock crosscut by leucogranite veins; some veins are folded (F4), others have intruded along fold axial surface.

tonic rock varying in composition from quartz diorite to granodiorite and containing dark, finegrained amphibolite xenoliths (fragments of volcanic rocks or mafic dikes). Migmatization of the older rocks by the Oripää granite has resulted in very heterogenous composition of the rocks around the quarry, with a variation from unmigmatized plutonic rock through granitized granodiorite to coarse leucogranite with abundant granodioritic to quartz dioritic and amphibolitic inclusions (Fig. 1d). Ac- cording to a previous study (Nironen, 1999) the pervasive foliation in the synorogenic tonalites and granodiorites in the Loimaa area is contemporaneous with the regional S2 foliation, modified by F3 folding with generally E-W trending axial plane. The Oripää granite has injected the synorogenic plutonic rock as veins subparallel to S2/S3 foliation (Fig. 1e). The synorogenic rock as well as the granite veins are openly to tightly and symmetrically folded with axial plane trending approximately N-S 
(regional F4 folding; Nironen, 1999). Granite veins are also present at the F4 axial surfaces (Fig. 1f).

\section{Samples}

We have collected five additional samples from the Oripää pluton and the vicinity and consider our new $\mathrm{Nd}$ isotope and elemental geochemical data on these samples together with data on the Oripää leucogranite sample from Rämö \& Nironen (2001). The new samples are:

Leucogranite MAN-2005-1.1 ( $\mathrm{N}=6759336$, $\mathrm{E}=3262996$ in Finnish National Coordinates) from the Oripää granite. The sample was taken from a homogeneous part of an overall heterogeneous rock. The granite is pink, coarse-grained, leucocratic biotite granite, similar to sample $10-\mathrm{MN}-93$ that was taken from the previous study of the Oripää granite (Rämö \& Nironen, 2001).

Quartz diorite MAN-2005-1.2 ( $\mathrm{N}=6759431$, $\mathrm{E}=3262962)$ from the main tonalite - quartz diorite. It is a darkish, foliated, medium-grained quartz diorite with hornblende and biotite as mafic minerals, and magnetite and apatite as abundant accessory minerals.

Amphibolite MAN-2005-1.3 ( $\mathrm{N}=6759323$, $\mathrm{E}=3262940)$ from an elongated amphibolite xenolith (possibly a mafic dike fragment) $20 \mathrm{~cm}$ in width. The amphibolite is a dark green, homogeneous, fine-grained, almost unfoliated rock that consists mainly of hornblende and plagioclase; biotite is found as minor constituent, and titanite, magnetite, and apatite as accessory minerals.

Amphibolite 190-MN-90 ( $\mathrm{N}=6757960, \mathrm{E}=$ 3266324 ) that surrounds the Oripää granite (Fig. 1). This amphibolite is more deformed and contains more biotite than the amphibolite from the xenolith (sample MAN-2005-1.3).

Tonalite 64-MN-92 $(\mathrm{N}=6790210, \mathrm{E}=$ 3266810 ) from a roadcut $30 \mathrm{~km}$ north of the Oripää quarry. The rock is a deformed tonalite with distinct foliation and mineral lineation; the grainsize varies from medium to fine. Biotite and hornblende are the mafic minerals, and alkali feldspar is found as a secondary mineral in interstices of plagioclase and quartz.

\section{Elemental geochemistry}

Whole-rock elemental geochemical data of the six samples are shown in Table 1 and in Fig. 2. The two samples from the Oripää granite (MAN-2005$1.1,10-\mathrm{MN}-93)$ are both marginally peraluminous (Fig. 2a) and leucocratic $\left(\mathrm{FeO}^{\text {tot }}+\mathrm{MgO}+\mathrm{TiO}_{2}\right.$ $<1.3$ wt. \%) but show marked differences in silica and rare earth element contents. Both are enriched in light REE (LREE) relative to heavy REE (HREE) (Fig. 2b) yet sample MAN-2005-1.1 that is lower in silica shows approximately 5 times higher concentrations of the LREE. Sample MAN-2005-1.1 shows a faint negative Eu anomaly whereas sample 10-MN-93 shows a positive Eu anomaly.

The synorogenic tonalite (64-MN-92) is relatively silicic $\left(\mathrm{SiO}_{2} 70.5\right.$ wt. \%), marginally peraluminous (Fig. 2a), and strongly enriched in the LREE (Fig. 2b). The quartz diorite (MAN-2005-1.2) is quite mafic (50.8 wt.\% $\mathrm{SiO}_{2}$ ), metaluminous (Fig. 2a), iron enriched (Fig. 2c), and enriched in the LREE (Fig. 2b). In terms of the REE, both the tonalite and the quartz diorite differ from the two leucogranites having clearly higher relative contents of the HREE (Fig. 2b). The two amphibolites are moderately evolved (Mg number -58 ; Table 1$)$. They straddle the boundary between the tholeiitic and calc-alkaline fields in the AFM diagram (Fig. 2c) and they are only moderately enriched in the LREE relative to the HREE (Fig. 2b).

\section{Nd isotopes}

Whole-rock $\mathrm{Nd}$ isotope data on the six samples are shown in Table 1, including those of the Oripää leucogranite sample 10-MN-93 reported earlier by Rämö \& Nironen (2001). The two granite samples analyzed from the Oripää granite quarry have quite varying $\mathrm{Sm}$ (1.36 ppm, $4.18 \mathrm{ppm})$ and $\mathrm{Nd}$ (8.85 ppm, $25.62 \mathrm{ppm}$ ) concentrations yet quite similar present-day ${ }^{147} \mathrm{Sm} /{ }^{144} \mathrm{Nd}(0.09263,0.09861)$ and ${ }^{143} \mathrm{Nd} /{ }^{144} \mathrm{Nd}(0.511500 \pm 0.000016,0.511518 \pm$ 0.000011 ) ratios (as determined by the ID-TIMS method; Table 1). Please note also that the Sm and Nd values determined for sample MAN-2005-1.1 by the ICP/MS method (6.33 ppm, $47.5 \mathrm{ppm}$ ) are 
Table 1. Elemental geochemical and Nd isotope composition of rock types at and around the Oripää quarry.

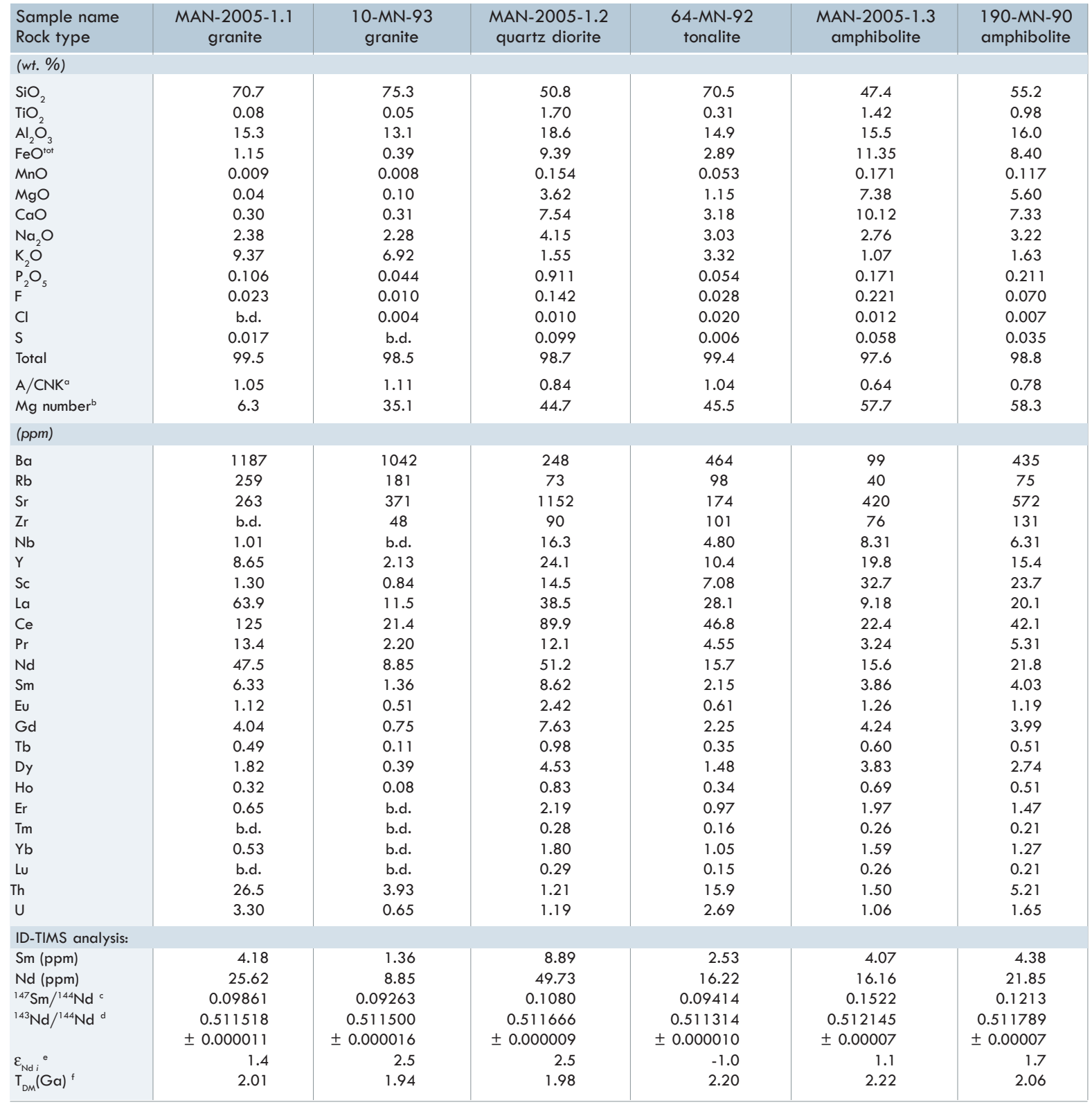

Note: Analyses at the Geological Survey of Finland (GTK). Major oxides, Ga, Rb, Sr, Ba, Nb, Zr, and Pb by XRF, other trace elements by ICP/MS. Whole-rock Sm-Nd isotope data by ID-TIMS at the GTK by the second author. Analytical methods as in Kurhila et al. (2010). Data on sample 10-MN-93 from Rämö \& Nironen (2001). b.d. = below detection limit.

a $\mathrm{Al} 2 \mathrm{O} 3 /(\mathrm{CaO}+\mathrm{Na} 2 \mathrm{O}+\mathrm{K} 2 \mathrm{O})$, atomic.

b $100 * \mathrm{MgO} /(\mathrm{MgO}+0.85 * \mathrm{FeOtot})$, atomic.

c error on $147 \mathrm{Sm} / 144 \mathrm{Nd}$ is $0.5 \%$.

d $143 \mathrm{Nd} / 144 \mathrm{Nd}$ normalized to $146 \mathrm{Nd} / 144 \mathrm{Nd}=0.7219$; reported error is $2 \sigma_{\mathrm{m}}$.

e Initial eNd value, calculated at $1850 \mathrm{Ma}$ (granites) and $1890 \mathrm{Ma}$ (quartz diorite, tonalite, amphibolites) using $143 \mathrm{Nd} /$ $144 \mathrm{Nd}=0.51264$ and $147 \mathrm{Sm} / 144 \mathrm{Nd}=0.1966$.

f Depleted mantle model age (DePaolo, 1981). 
a

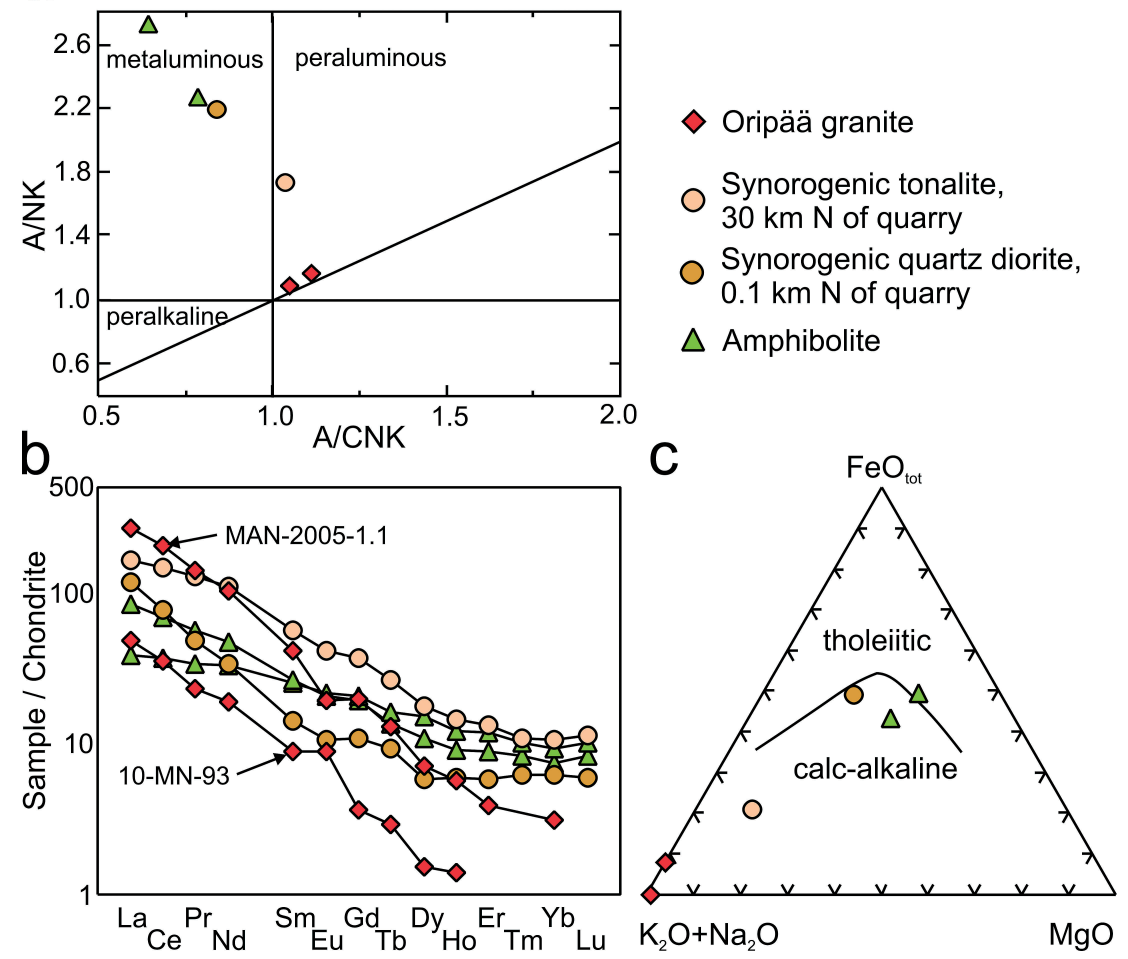

Fig. 2. Geochemistry of the rocks at and around the Oripää quarry. a) Molecular $\mathrm{A} /$ $\mathrm{NK}\left[\mathrm{Al}_{2} \mathrm{O}_{3} /\left(\mathrm{Na}_{2} \mathrm{O}+\mathrm{K}_{2} \mathrm{O}\right)\right]$ vs. $\mathrm{A} /$ $\mathrm{CNK} \quad\left[\mathrm{Al}_{2} \mathrm{O}_{3} /\left(\mathrm{CaO}+\mathrm{Na}_{2} \mathrm{O}+\right.\right.$ $\mathrm{K}_{2} \mathrm{O}$ )] diagram (cf. Maniar \& Piccoli, 1989). b) Rare earth element composition, normalized against chondrite (Boynton, 1984). c) Alkali-iron-magnesium (AFM) diagram (cf. Irvine \& Baragar, 1971). distinctly higher than those determined by the IDTIMS method (4.18 ppm, $25.62 \mathrm{ppm}$ ). This probably stems from monazite-related nugget effect (more monazite in the powder batch used for the ICP/MS analysis).

The initial $\varepsilon_{\mathrm{Nd}}$ (at $1850 \mathrm{Ma}$ ) values of the leucogranites are +1.4 (MAN-2005-1.1) and +2.5 (10MN-93). The result of the new analysis (MN-2005$1.1)$ is thus almost identical within the experimental error $\left( \pm 0.4 \varepsilon_{\mathrm{Nd}}\right.$ units $)$ to the value published in 2001 for sample 10-MN-93 (Table 1; Rämö \& Nironen, 2001), and confirms the juvenile $\mathrm{Nd}$ isotopic character of the Oripää leucogranite. The synorogenic quartz diorite (MAN-2005-1.2) close to the Oripää granite has an $\varepsilon_{\mathrm{Nd}}$ (at $1890 \mathrm{Ma}$ ) value of +2.5 and is, in this respect, thus quite similar to the Oripää granite. In contrast, the synorogenic tonalite (64-MN-92) that is located about $30 \mathrm{~km}$ north of the Oripää granite quarry (Fig. 1) is clearly less radiogenic $\left[\varepsilon_{\mathrm{Nd}}(\right.$ at $\left.1890 \mathrm{Ma})-1.0\right]$ than the quartz diorite. The two amphibolites have similar $\varepsilon_{\mathrm{Nd}}$ (at $1890 \mathrm{Ma})$ values $(+1.1$ and +1.7$)$ as the quartz dio- rite and the Oripää granite samples, but they have somewhat higher ${ }^{147} \mathrm{Sm} /{ }^{144} \mathrm{Nd}$ values (Table 1 ).

\section{Discussion and conclusions}

The two leucogranite samples analyzed from the Oripää pluton record the typical compositional heterogeneity (e.g., substantial variation in $\mathrm{SiO}_{2}$ and REE) of the leucogranites of the LSGM zone that reflects migmatization and anatexis of heterogeneous crustal domains that probably comprised both igneous and metasedimentary rocks, and subsequent fractionation of the magmas (e.g., Johannes et al., 2003; Kurhila et al., 2005, 2010; Ståhlfors \& Ehlers, 2005; Kukkonen \& Lauri 2009). The samples do not show negative Eu anomalies that are typical of evolved granites in the LSGM zone (e.g., Stålfors \& Ehlers, 2006; Nironen \& Kurhila, 2008); the positive Eu anomaly of sample 10-MN-93 is in line with the previously suggested cumulate origin (Rämö \& Nironen, 2001). Thus, the Oripää grani- 
te, with low $\mathrm{TiO}_{2}, \mathrm{FeO}^{\text {tot }}$ and $\mathrm{MgO}$ contents and variable $\mathrm{REE}$ contents, may be considered as a cumulate that remained after escape of an evolved granite melt (cf. Johannes et al., 2003) or, alternatively, a minimum melt relatively enriched in felsic components.

The emplacement age of the Oripää granite is somewhat ambiguous. There are two distinct zircon populations in the Oripää granite, one of them prismatic, stubby, and brownish; the other anhedral and transparent (Nironen, 1999; Kurhila et al., 2005). In situ SIMS U-Pb work on these revealed upper intercept ages of $1872 \pm 10 \mathrm{Ma}$ and $1850 \pm$ $16 \mathrm{Ma}$, respectively (Kurhila et al., 2005). The older population may be inherited from the source of the granite, the younger could represent crystallization of the leucogranite (Kurhila et al., 2005). This would then clearly predate a previously determined 1794 $\pm 10 \mathrm{Ma} \mathrm{U}-\mathrm{Pb}$ monazite age of the Oripää granite
(Nironen, 1999); the monazite would register a later metamorphic event. Our field studies, with granite veins both deformed by F4 folding and injected at F4 axial planes, indicate that if $-1850 \mathrm{Ma}$ is the emplacement age of the Oripää granite, this is also the age of regional F4 folding.

The $\mathrm{Nd}$ isotope composition of our samples provides a piercing point for Paleoproterozoic magmatic processes on the northwestern flank of the LSGM zone. The initial $\mathrm{Nd}$ isotope composition of the six samples is shown in an $\varepsilon_{\mathrm{Nd}}$ versus age diagram in Fig. 3. They are also compared with published $\mathrm{Nd}$ isotope data of the synorogenic granites of the Arc complex of western Finland (gray evolution lines) and the Arc complex of southern Finland (dashed lines) (data from Huhma, 1986; Patchett \& Kouvo, 1986; Rämö et al., 2001; Kurhila et al., 2005). In the $\varepsilon_{\mathrm{Nd}}$ versus age diagram, the Oripää granite and the quartz diorite are markedly

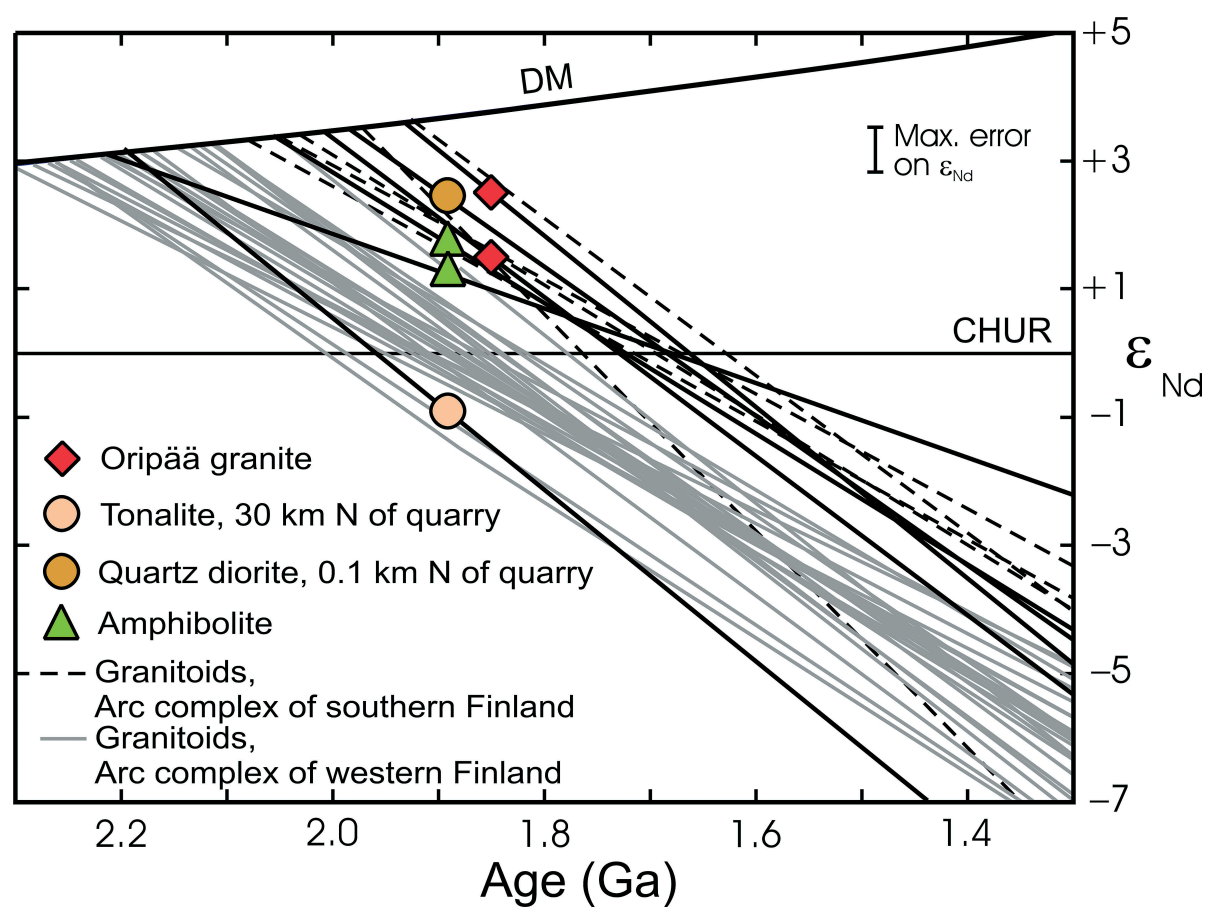

Fig. 3. $\varepsilon_{\mathrm{Nd}}$ vs. age diagram showing the initial Nd isotope composition (Table 1) of the Oripää granite (two samples) and country-rock tonalite, quartz diorite, and amphibolite (two samples). Evolution lines (black, solid) of the samples are also shown, as are those of granitoids from the northern segment of the Arc complex of southern Finland and the Arc complex of western Finland (data from Huhma, 1986; Patchett \& Kouvo, 1986; Rämö et al., 2001; and Kurhila et al., 2005; see also Rämö et al., 2004). CHUR is Chondritic Uniform Reservoir (DePaolo \& Wasserburg, 1976) and DM the depleted upper mantle of DePaolo (1981). Maximum error in $\varepsilon_{\mathrm{Nd}}$ is shown at the $95 \%$ confidence level. 
similar to the granitoids of the northern segment of the Arc complex of southern Finland - the latter have $\varepsilon_{\mathrm{Nd}}($ at $-1.9 \mathrm{Ga})$ values on the order of +1 to +3 . The Oripää granites, amphibolites, and quartz diorite are also mutually quite similar, which is compatible with the idea that the Oripää granite was derived from local sources (Nironen, 1999). The tonalite about $30 \mathrm{~km}$ north of the Oripää granite is much less juvenile than the other sampes and complies with the evolution path of the synorogenic granitoids from the Arc complex of western Finland these granitoids have $\varepsilon_{\mathrm{Nd}}($ at $-1.9 \mathrm{Ga})$ values of -1 to +1 (Rämö et al., 2001). At the longitude of Oripää, the boundary between the two arc complexes has been placed about $50 \mathrm{~km}$ north of the granite (Korsman et al., 1997; see also Lahtinen \& Huhma, 1997 and Rämö et al., 2001). Our data support, on $\mathrm{Nd}$ isotopic grounds, the existence of two arc complexes and suggest that the terrane boundary between these compexes is located some $20 \mathrm{~km}$ farther south than hithertho believed.

\section{Acknowledgments}

Critical reviews by Dr. Hannu Huhma and Dr. Markku Väisänen improved the text. Tuula Hokkanen kindly helped in chemical purification of Sm and Nd for ID-TIMS measurements. This is a contribution to the Academy of Finland project \# 54088 (Late-orogenic granites of the Finnish Svecofennian - origin and tectonic significance).

\section{References}

Boynton, W.V., 1984. Geochemistry of the rare earth elements: meteorite studies. In: Henderson, P. (ed.) Rare Earth Element Geochemistry. Elsevier, Amsterdam, 63-114.

DePaolo, D.J., 1981. Neodymium isotopes in the Colorado Front Range and crust-mantle evolution in the Proterozoic. Nature 291, 193-196.

DePaolo, D.J. \& Wasserburg, G.J., 1976. Nd isotopic variations and petrogenetic models. Geophysical Research Letters 3, 249-252.

Ehlers, C., Lindroos, A. \& Selonen, O., 1993. The late Svecofennian granite-migmatite zone of southern Finland - a belt of transpressive deformation and granite emplacement. Precambrian Research 64, 295-309.

Huhma, H., 1986. Sm-Nd, U-Pb and Pb-Pb isotopic evidence for the origin of the early Proterozoic Svecokarelian crust in Finland. Geological Survey of Finland, Bulletin $337,1-52$.
Irvine, T.N. \& Baragar, W.R.A., 1971. A guide to the classification of the common volcanic rocks. Canadian Journal of Earth Sciences 8, 523-548.

Johannes, W., Ehlers, C., Kriegsman, L.M. \& Mengel, K., 2003. The link between migmatites and S-type granites in the Turku area, southern Finland. Lithos 68, 69-90.

Korsman, K., Koistinen, T., Kohonen, J., Wennerström, M., Ekdahl, E., Honkamo, M., Idman, H. \& Pekkala, Y. (eds.) 1997. Suomen kallioperäkartta - Berggrundskarta över Finland - Bedrock map of Finland. 1 : 1000 000. Geological Survey of Finland, Espoo.

Kukkonen, I.T. \& Lauri, L.S., 2009. Modelling the thermal evolution of a collisional Precambrian orogen: High heat production migmatitic granites of southern Finland. Precambrian Research 168, 233-246.

Kurhila, M., Vaasjoki, M., Mänttäri, I., Rämö, O.T. \& Nironen, M., 2005. U-Pb ages and $\mathrm{Nd}$ isotope characteristics of the lateorogenic, migmatizing microcline granites in southwestern Finland. Bulletin of the Geological Society of Finland 77, 105-128.

Kurhila, M., Andersen, T. \& Rämö, O.T., 2010. Diverse sources of crustal granitic magma: $\mathrm{Lu}-\mathrm{Hf}$ isotope data on zircon in three Paleoproterozoic leucogranites of southern Finland. Lithos 115, 263-271.

Kurhila, M., Mänttäri, I., Vaasjoki, M., Rämö, O.T. \& Nironen, M., 2011. U-Pb geochrological constraints of the late Svecofennian leucogranites of southern Finland. Precambrian Research 190, 1-24.

Lahtinen, R. \& Huhma, H., 1997. Isotopic and geochemical constraints on the evolution of the 1.93-1.79 Ga Svecofennian crust and mantle in Finland. Precambrian Research 82, 13-34.

Maniar, P.D. \& Piccoli, P.M., 1989. Tectonic discrimination of granitoids. Bulletin of the Geological Society of America $101,635-643$.

Nironen, M., 1999. Structural and magmatic evolution in the Loimaa area, southwestern Finland. Bulletin of the Geological Society of Finland 71, 57-71.

Nironen, M. \& Kurhila, M., 2008. The Veikkola granite area in southern Finland: emplacement of a 1.83-1.82 Ga plutonic sequence in an extensional regime. Bulletin of the Geological Society of Finland 80, 39-68.

Patchett, J. \& Kouvo, O., 1986. Origin of continental crust of 1.9-1.7 Ga age: $\mathrm{Nd}$ isotopes and U-Pb zircon ages in the Svecokarelian terrain of south Finland. Contributions to Mineralogy and Petrology 92, 1-12.

Rämö, O.T. \& Nironen, M., 2001. The Oripää granite, SW Finland: Characterization and significance in terms of Svecofennian crustal evolution. Bulletin of the Geological Society of Finland 73, 103-109.

Rämö, O.T., Vaasjoki, M., Mänttäri, I., Elliott, B.A. \& Nironen, M., 2001. Petrogenesis of the post-kinematic magmatism of the Central Finland Granitoid Complex I; Radiogenic isotope constraints and implications for crustal 
evolution. Journal of Petrology 42, 1971-1993.

Rämö, O.T., Kurhila, M., Nironen, M., Vaasjoki, M., Mänttäri, I. \& Elliott, B.A., 2004. Nd isotope variation in the lateorogenic microcline granites and their synorogenic country rock granitoids in southern Finland. In: Mansfeld, J. (ed.) The 26th Nordic Geological Winter Mee- ting, Abstract Volume. GFF 126 (part 1), 34.

Ståhlfors, T. \& Ehlers, C., 2006. Emplacement mechanisms of late-orogenic granites: structural and geochemical evidence from southern Finland. International Journal of Earth Sciences 95, 557-568. 